\title{
Penyuluhan Hukum Tentang Peran Majelis Krama Desa Dalam Mencegah Perkawinan Anak Di Kabupaten Lombok Utara
}

\author{
RR. Cahyowati ${ }^{*}$, Rodliyah ${ }^{1}$, Risnain $^{1}$ \\ ${ }^{1}$ Fakultas Hukum, Universitas Mataram, Mataram, Indonesia.
}

\section{Article Info}

Received: November 20th 2020

Revised: December 25th, 2020

Accepted: December 30th, 2020

\begin{abstract}
Abstrak: Angka perkawinan anak di Indonesia tertinggi kedua setelah Kamboja untuk kawasan regional ASEAN. Perkawinan anak ini perlu mendapat perhatian serius karena mengakibatkan hilangnya hak-hak anak perempuan, seperti pendidikan, bermain, perlindungan, keamanan, dan lainnya termasuk dampak atas kesehatan. Permasalahan yang dihadapi di NTB adalah tingginya perkawinan usia anak, masuk dalam ranking 10 Nasional. Tujuan penyuluhan ini adalah untuk memberikan pengetahuan kepada masyarakat di Desa Bentek mengenai Peran Majelis Krama Desa mencegah terjadinya perkawinan usia anak di Kabupaten Lombok Utara. Hasil, Majelis Krama Desa di Desa Bentek terdiri dari 9 pengurus dengan biaya operasional tahun 2020 sebesar Rp. 20.000.000,-, perkara yang diajukan masyarakat di Desa Bentek diselesaikan di "Berugak", sehingga tidak terlalu banyak masalah masyarakat yang masuk ke ranah kepolisian. Adanya Majelis Krama Desa merupakan salah satu kewenangan lokal berskala desa yang mempunyai tugas dan fungsi untuk membina kerukunan masyarakat desa, memelihara perdamaian dan menangani sengketa yang ada di desa dengan pendekatan hukum adat berlandaskan norma budaya dan nilai-nilai kearifan lokal.

Kata Kunci: Penyuluhan Hukum; Majelis Krama Desa; Perkawinan Anak.

Abstract: The number of child marriage in Indonesia is the second highest after Cambodia for the ASEAN region. Child marriage needs serious attention because it results in the loss of girls' rights, such as education, play, protection, security, and others, including the impact on health. The problem faced in NTB is the high number of child marriages, which are in the 10th National ranking. The purpose of this counseling is to provide knowledge to the community in Bentek Village regarding the Role of the Krama Desa Council in preventing child marriage in North Lombok Regency. As a result, the Krama Desa Assembly in Bentek Village consists of 9 administrators with an operational cost in 2020 of Rp. 20,000,000-, cases filed by the community in Bentek Village are resolved in "Berugak", so that not too many community problems enter the realm of the police. The Krama Desa Council is one of the village-scale local authorities that has the task and function of fostering village community harmony, maintaining peace and handling disputes in the village with a customary law approach based on cultural norms and local wisdom values.

Keywords: Legal Education; Village Krama Council; Child Marriage.
\end{abstract}

Citation: Cahyowati, R., Rodliyah., \& Risnain (2020). Penyuluhan Hukum Tentang Peran Majelis Krama Desa Dalam Mencegah Perkawinan Anak Di Kabupaten Lombok Utara. Unram Journal of Community Service 1(1), 20-24

\section{Pendahuluan}

Pernikahan anak menjadi salah satu pelanggaran hak anak yang masih terjadi di Indonesia. Angka perkawinan anak di Indonesia tertinggi kedua setelah Kamboja untuk kawasan regional ASEAN. Perkawinan anak ini perlu mendapat perhatian serius karena mengakibatkan hilangnya hak-hak anak perempuan, seperti pendidikan, bermain, perlindungan, keamanan, dan lainnya termasuk dampak atas kesehatan (Azzahra,
2020).

Provinsi Nusa Tenggara Barat (NTB) dengan jumlah penduduk pada tahun 2018 sebanyak 5 152.400 jiwa, laki-laki sebanyak 2.522 .600 jiwa (48, $96 \%$ ) ,dan perempuan 2.629 .800 jiwa $(51,04 \%)$ (BPS, 2018). Permasalahan yang dihadapi di NTB adalah tingginya perkawinan usia anak, masuk dalam ranking 10 Nasional. Provinsi NTB memiliki prevalen si perkawinan usia anak tertinggi untuk wilayah Jawa Bali dan Nusa Tenggara sebesar 15,48 persen (BPS, 2020). 
Maraknya pernikahan anak di NTB, diikuti dengan upaya pencegahan perkawinan. Dari 43 kasus perkawinan anak yang dapat dicegah di NTB, 26 kasus $(60,47 \%)$ berada di Kabupaten Lombok Utara (Lombok Post, 2020). Upaya pencegahan terhadap perkawinan anak di Kabupaten Lombok Utara dilakukan oleh Majelis Krama Desa yang anggotanya terdiri dari Penghulu Desa, Tokoh Agama, Tokoh Adat, dan Tokoh Masyarakat.

Berdasar hasil analisis situasi, maka dapat diidentifikasi permasalahan seperti: Bagaimana Peran Majelis Krama Desa mencegah terjadinya perkawinan usia-anak di Kabupaten Lombok Utara? Target yang ingin dicapai adalah, mensosialisasikan dan memberdayakan peran Majelis Krama Desa dalam mencegah terjadinya perkawinan usia anak di Desa Bentek Kabupaten Lombok Utara.

\section{Metode Pelaksanaan}

Metode yang digunakan dalam kegiatan ini dilakukan dengan ceramah (dialog dua arah), antara tim dengan masyarakat. Sebelum dilaksanakan penyuluhan, tim mempersiapkan:

1) Bahan hukum primer, yaitu menginventarisir peraturan-peraturan tentang peran Majelis Krama Desa dalam pencegahan perkawinan usia anak di Kabupaten Lombok Utara

2) Membuat hand out yang dibagikan kepada masyarakat, sebagai bahan untuk dibaca dan dipelajari sehingga ada bahan rujukan yang dapat disebarluaskan kepada masyarakat.

3) Menghimpun kasus-kasus yang ditanyakan peserta penyuluhan, sebagai bahan untuk melakukan penelitian berikutnya, dan bahan kuliah Hukum Kenegaraan.

\section{Hasil dan Pembahasan}

\section{Perkawinan Anak}

Pengertian perkawinan anak adalah perkawinan dimana calon mempelai belum berusia 18 tahun (Suerti, 2019). Perkawinan anak merupakan salah satu bentuk tindak kekerasan terhadap anak. Anak yang dipaksa menikah atau karena kondisi tertentu harus menikah di bawah usia 18 tahun akan memiliki kerentanan yang lebih besar baik secara akses pendidikan, kualitas kesehatan, potensi mengalami tindak kekerasan, serta hidup dalam kemiskinan. Dampak perkawinan anak tidak hanya akan dialami oleh anak yang dinikahkan, namun juga akan berdampak pada anak yang dilahirkan serta berpotensi memunculkan kemiskinan antar generasi (BPS, 2019).

Perkawinan anak adalah isu yang kompleks. Faktor-faktor yang ditengarai berkontribusi adalah faktor kemiskinan, geografis, kurangnya akses terhadap pendidikan, ketidaksetaraan gender, konflik sosial dan bencana, ketiadaan akses terhadap layanan dan informasi kesehatan reproduksi yang komprehensif, norma sosial yang menguatkan stereotipe gender tertentu (misalnya, perempuan seharusnya menikah muda), dan budaya (interpretasi agama dan tradisi lokal) (Sueri, 2019).

Di NTB, persoalan perkawinan usia anak merupakan persoalan tersendiri sehingga upaya pencegahan perkawinan usia anak, telah dikeluarkan Edaran Gubernur NTB No.180/1153/Kum Tahun 2014 yang mengatur usia perkawinan ideal bagi laki-laki dan perempuan adalah 21 tahun (Cahyowati, 2019). Kebijakan ini dikeluarkan dengan pertimbangan: 1) Usia 21 tahun telah menyelesaikan pendidikan di SMA atau sederajat, sehingga wajib belajar (Wajar) 12 tahun sudah dituntaskan; 2) Usia 21 tahun secara psikologis dianggap sudah siap untuk menerima tanggungjawab ketika membina rumah tangga; 3) Usia 21 tahun sudah bekerja.

Kebijakan pendewasaan usia perkawinan anak ini juga diikuti oleh kabupaten/kota di NTB, diantaranya:

a. Kabupaten Lombok Barat melakukan pendataan by name by addres di semua kecamatan, termasuk di wilayah Lembar, Batu Layar, dan Sekotong. dengan melibatkan pembantu penyuluh keluarga berencana desa (PPKBD), membuat awik-awik di desa, dibentuk Komisi Perlindungan Anak Desa (KPAD), dan perlindungan anak terpadu berbasis masyarakat. Kendala yang dihadapi adalah minimnya anggaran untuk kegiatan ini.

b. Pemerintah Kabupaten Bima, membuat kebijakan tidak menerbitkan akta nikah bagi pasangan yang menikah di bawah umur. Hal ini disosialisasikan ke desa- desa, sehingga para orang tua yang berminat menikahkan putra putri mereka di bawah umur berpikir ulang. Begitu juga calon pengantin, tentu tidak ingin bermasalah kemudian hari karena pernikahan mereka tidak tercatat. Pemerintah kabupaten Bima, meminta calon mempelai menunjukkan ijazah SMA ketika ingin mendaftarkan diri menikah. Hal ini dimaksudkan menyukseskan program wajib belajar 12 tahun.

c. Di Kabupaten Lombok Utara, menggagas peraturan desa untuk pendewasaan usia perkawinan, dimana desa dan dusun merupakan ujung tombak yang efektif untuk mencegah pernikahan usia dini. Melalui peraturan desa yang mengatur usia boleh menikah, dengan sejumlah konsekuensi apabila menikah di bawah umur tidak akan mendapat hak-hak kependudukan.

Ternyata implementasi pendewasaan perkawinan usia anak ternyata bervariasi, contohnya di 
Kabupaten Lombok Utara, berbeda dengan Surat Edaran Gubernur NTB No.180/1153/Kum Tahun 2014 yang menghendaki usia perkawinan ideal bagi laki-laki dan perempuan adalah 21 tahun. Ada 5 (lima) Peraturan Desa yang dikaji di Kabupaten Lombok Utara tentang Usia Mamulang / perkawinan. Peraturan Desa ini difasilitasi oleh Lembaga Perlindungan Anak (LPA) Provinsi NTB, yaitu:

1) Peraturan Desa Loloan No.3 Tahun 2016 tentang Usia Memulang;

2) Peraturan Desa Anyar Nomor 1 Tahun 2017 tentang Usia Memulang;

3) Peraturan Desa Bayan Nomor 1 Tahun 2017 tentang Umur Memulang;

4) Peraturan Desa Sambik Elen Nomor 15 Tahun 2017 tentang Umur Memulang.

Batas usia perkawinan yang diharapkan dalam Peraturan Desa tersebut, adalah perempuan telah berusia 19 tahun, dan laki-laki telah berusia 21 tahun. Hal ini disesuaikan dengan kondisi masyarakat setempat, dimana usia 19 tahun bagi perempuan dianggap telah menyelesaikan wajib belajar 12 tahun atau telah menyelesaikan tingkat pendidikan di SMA atau sederajat, sedangkan laki-laki yang berumur 21 tahun, disamping telah menyelesaikan pendidikan SMA atau sederajat, juga sudah bekerja.

Berdasarkan hasil penelitian yang dilakukan Biro Pusat Statistik (BPS) tahun 2016 yang didanai oleh UNICEF12, perkawinan usia anak di Indonesia tetap tinggi, dimana anak-anak perempuan di bawah usia 15 tahun telah mengalami penurunan terbesar, tetapi diantara anak-anak perempuan usia 16-17 tahun prevalensi perkawinan usia anak mengalami peningkatan. Di sekolah menengah memberikan dampak besar untuk membantu anak-anak perempuan ini menunda perkawinan hingga mereka dewasa. Hasil laporan ini, menunjukan bahwa perkawinan usia anak terjadi pada semua wilayah di Indonesia yang menempatkan bahwa praktik ini mengakar dalam norma-norma sosial dan budaya secara ketat, hal ini juga terjadi di NTB. Dampak adanya usia perkawinan anak, adalah (BPS, 2016):

1. Menyebabkan kehamilan dan persalinan dini yang berhubungan dengan angka kematian yang tinggi dan keadaan tidak normal karena tubuh anak memasuki masa dewasa;

2. Praktik perkawinan usia anak, seringkali menimbulkan dampak buruk terhadap status kesehatan, pendidikan, ekonomi, keamanan anak perempuan dan anak- anak mereka serta menimbulkan dampak yang merugikan bagi masyarakat;

3. Anak perempuan usia $10-14$ tahun memiliki resiko 5 kali lebih besar untuk meninggal dalam kasus kehamilan dan persalinan daripada perempuan usia 20-24 tahun;

4. Anak perempuan yang telah menikah cenderung memiliki tingkat pendidikan yang lebih rendah, data menunjukan $85 \%$ anak perempuan di Indonesia mengakhiri pendidikan mereka setelah mereka menikah.

Dampak dari perkawinan usia anak dikuatkan dengan hasil penelitian kerjasama Kementerian Pemberdayaan Perempuan dan Perlindungan Anak Republik Indonesia-Yayasan Melati, dan Pusat kajian Gender dan Anak Institut Pertanian Bogor yaitu: 1) Peningkatan resiko anak hidup dalam kemiskinan; 2) Peningkatan resiko anak tidak memiliki buku nikah karena perkawinannya tidak dapat dicatatakan; 3) Rendahnya ketrampilan pengasuhan anak (Laporan Akhir, 2016).

\section{Majelis Krama Desa}

Di Kabupaten Lombok Utara telah dikeluarkan Peraturan Bupati Lombok Utara Nomor 20 Tahun 2017 tentang Pedoman Majelis Krama Desa (selanjutnya disingkat MKD), peraturan ini dihajatkan untuk menyelesaikan persoalan-persoalan yang ada di Desa. Keberadaan MKD diharapkan dapat mengakomodasi penyelesaian permasalahan dengan pendekatan hukum adat berlandaskan norma budaya dan nilai-nilai kearifan lokal yang bestari di masyarakat. Jalan keluar masalah yang terjadi di masyarakat dapat diselesaikan di "Berugak", sehingga tidak terlalu banyak masalah masyarakat yang masuk ke ranah kepolisian. Kabupaten Lombok Utara merupakan kabupaten dengan angka kriminalitas paling rendah di NTB.

MKD merupakan salah satu kewenangan lokal berskala desa, hal ini diatur dalam Pasal 19 b UU No.6 Tahun 2014 tentang Pemerintahan Desa, dalam penjelasan Pasal 19 b, dinyatakan "kewenangan lokal berskala Desa" adalah kewenangan untuk mengatur dan mengurus kepentingan masyarakat Desa yang telah dijalankan oleh Desa atau mampu dan efektif dijalankan oleh Desa atau yang muncul karena perkembangan Desa dan prakasa masyarakat Desa. Dibentuknya MKD mempunyai tugas dan fungsi untuk membina kerukunan masyarakat desa, memelihara perdamaian dan menangani sengketa yang ada di desa serta membantu pemerintah dalam memfasilitasi penyelesaian sengketa di wilayah kerja masing-masing. Adanya MKD tercantum dalam rancangan RPJMD tahun 2016-2021, yaitu menumbuh kembangkan strategi dan arah strategis terintegrasi dengan nilai luhur budaya yang ada di masyarakat (Sofian, 220). Hal ini dimaksudkan untuk penyelesaian sengketa melalui musyawarah mufakat yang hidup dan berkembang dalam kehidupan masyarakat di Kabupaten Lombok Utara yang 
merupakan kearifan lokal. MKD sebagai bagian dari Lembaga Kemasyarakatan Desa, dan membina kerukunan warga masyarakat Desa, memelihara perdamaian, menangani konflik dan melakukan medias.

Adanya Krama Adat Desa merupakan lembaga yang memiliki peran strategis dalam penyelesaian konflik lokal di masyarakat Desa dengan merevitaliasasi nilai budaya lokal melalui penegakan awig-awig (peraturan adat).

Fungsi Majelis Krama Desa adalah 1) Memfasilitasi mediasi sengketa yang terjadi di masyarakat Desa; 2) Mengembangkan koordinasi dan kerjasama antar lembaga desa dan Pemerintah Desa dalam menyelamatkan dan melestarikan nilai-nilai budaya yang tumbuh dan berkembang di Desa; dan 3) Mendokumentasi dan menginventarisasi nilai-nilai dan norma yang dikembangkan atau berkembang di masyarakat Pelayanan Publik yang dilakukan oleh penyelenggara Pelayanan Publik. Lingkup sengketa yang dapat diajukan penanganannya kepada MKD adalah: a) Tindak Pidana Ringan yang termasuk sebagai delik aduan; b) perkara perdata; atau c) sengketa adat.

MKD yang diatur dalam Peraturan Bupati Lombok Utara Nomor 20 Tahun 2017 tentang Pedoman Majelis Krama Desa, dihajatkan untuk menyelesaikan persoalan-persoalan yang ada di Desa. Keberadaan MKD diharapkan dapat mengakomodasi penyelesaian permasalahan dengan pendekatan hukum adat berlandaskan norma budaya dan nilainilai kearifan lokal yang bestari di masyarakat. Jalan keluar masalah yang terjadi di masyarakat dapat diselesaikan di "Berugak", sehingga tidak terlalu banyak masalah masyarakat yang masuk ke ranah kepolisian. Lombok Utara merupakan kabupaten dengan angka kriminalitas paling rendah di NTB

MKD merupakan salah satu kewenangan lokal berskala desa. mengamanatkan agar di desa dibentuk lembaga atau majelis krama desa yang mempunyai tugas dan fungsi untuk membina kerukunan masyarakat desa, memelihara perdamaian dan menangani sengketa yang ada di desa serta membantu pemerintah dalam memfasilitasi penyelesaian sengketa di wilayah kerja masingmasing.Ditambahkannya, pembentukan MKD di 33 desa telah dilaksanakan secara bertahap sejak peraturan tersebut ditetapkan. Pada 2017 terbentuk 15 MKD, dan pada tahun 2018 terbentuk 28 MKD. Pengukuhannya digelar pada tanggal 1 Januari 2018 oleh Kementrian Dalam Negeri Republik Indonesia. Keharusan adanya MKD tercantum dalam rancangan RPJMD tahun 2016-2021, yaitu menumbuh kembangkan strategi dan arah strategis terintegrasi dengan nilai luhur budaya yang ada di masyarakat
(Sofian, 220).

Dasar pertimbangan dikeluarkan Peraturan Bupati Lombok Utara Nomor 20 Tahun 2017 adalah untuk penyelesaian sengketa melalui musyawarah mufakat yang hidup dan berkembang dalam kehidupan masyarakat di Lombok Utara, hal ini juga merupakan kearifan lokal yang perlu dijaga kelestariannya sehingga diperlukan MKD sebagai bagian dari Lembaga Kemasyarakatan Desa, dan membina kerukunan warga masyarakat Desa, memelihara perdamaian, menangani konflik dan melakukan mediasi di Desa merupakan salah satu Kewenangan lokal berskala Desa di bidang pembinaan kemasyarakatan Desa.

Adanya MKD merupakan lembaga yang memiliki peran strategis dalam penyelesaian konflik lokal di masyarakat Desa dengan merevitaliasasi nilai budaya lokal melalui penegakan awig-awig (peraturan adat).

\section{Kesimpulan}

MKD di Kabupaten Lombok Utara dihajatkan untuk menyelesaikan persoalan-persoalan yang ada di Desa, untuk mengakomodasi penyelesaian permasalahan dengan pendekatan hukum adat berlandaskan norma budaya dan nilai-nilai kearifan lokal yang bestari di masyarakat, termasuk upaya pencegahan perkawinan anak. MKD merupakan salah satu kewenangan lokal berskala desa yang mempunyai tugas dan fungsi untuk membina kerukunan masyarakat desa, memelihara perdamaian dan menangani sengketa yang ada di desa serta membantu pemerintah dalam memfasilitasi penyelesaian sengketa di wilayah kerja masing-masing. MKD di Desa Bentek terdiri dari 9 pengurus dengan biaya operasional tahun 2020 sebesar Rp. 20.000.000,-, perkara yang diajukan masyarakat di Desa Bentek diselesaikan di "Berugak", sehingga tidak terlalu banyak masalah masyarakat yang masuk ke ranah kepolisian. Dengan adanya MKD, Kabupaten Lombok Utara merupakan kabupaten dengan angka kriminalitas paling rendah di NTB.

\section{Ucapan Terimakasih}

Ucapan terima kasih disampaikan kepada Rektor Universitas Mataram, Ketua LPPM Universitas Mataram, dan Dekan Fakultas Hukum Universitas Mataram yang telah mengalokasi anggaran dan memfasilitasi sehingga kegiatan Pengabdian Pada Masyarakat dapat terselenggara dengan baik, Kepala Desa Bentek-Kecamatan Gangga-Kabupaten Lombok Utara, dan masyarakat yang telah berpartisipasi pada penyuluhan hokum. 


\section{Daftar Pustaka}

Azzahra, Q. (2020). Angka Perkawinan Anak Indonesia, Tertinggi Kedua di ASEAN https://www.gatra.com/detail/news/428942/ milenial/angka- perkawinan-anak-indonesia tertinggi-kedua-di-asean, diunduh Sabtu 31 Oktober 2020

Badan Pusat Statistik (BPS). (2016). Kemajuan Yang Tertunda: Analisis Data Perkawinan Usia Anak di Indonesia Berdasarkan Hasil Susenas 2008-2012 dari Sensus Penduduk 2010, Jakarta.

Badan Pusat Statistik (BPS). (2018). Berapa Jumlah Penduduk Bali dan Nusa Tenggara? https://databoks.katadata.co.id/datapublish/20 19/07/06/berapa-jumlah-penduduk- bali-dannusa-tenggara, diunduh Sabtu, 21 November 2020

Badan Pusat Statistik (BPS). (2020). Kementerian Perencanaan Pembangunan Nasional, Pencegahan Perkawinan Anak: Percepatan Yang Tidak Bisa Ditunda, UNICEF, PUSKAPA, Jakarta

Cahyowati, R. (2019). Kebijakan Pendewasaan Perkawinan Usia Anak Di Provinsi Nusa Tenggara Barat, Editor: Ani Purwanti, Kunthi Tridewiyanti, Stop Perkawinan Anak Dan Penghapusan Kekerasan Seksual Bagi Perempuan Dan Anak, Penerbit Thafa Media, Yogyakarta.

Edaran Gubernur NTB No.180/1153/Kum Tahun 2014 tentang Usia Perkawinan Ideal Bagi Laki-laki Dan Perempuan

Kerjasama Kementerian Pemberdayaan Perempuan dan Perlindungan Anak RI- Yayasan MelatiPusat Kajian Gender dan Anak Lembaga Penelitian dan Pengabdian Kepada Masyarakat, Institut Pertanian Bogor, (2016). Laporan Akhir; Telaah Kebijakan Kajian Pendewasaan Usia Perkawinan Anak di Provinsi Bangka-Belitung.

Lombok Post. (2020). Nyaris Menikah, Dua Anak Dikirim ke Ponpes", Selasa 13 Oktober 2020.

Peraturan Bupati Lombok Utara Nomor 20 Tahun 2017 tentang Pedoman Majelis Krama Desa

Peraturan Desa Loloan No.3 Tahun 2016 tentang Usia Memulang; Peraturan Desa Anyar Nomor 1 Tahun 2017 tentang Usia Memulang; Peraturan Desa Bayan Nomor 1 Tahun 2017 tentang Umur Memulang

Peraturan Desa Sambik Elen Nomor 15 Tahun 2017 tentang Umur Memulang

Peraturan Perundang-Undangan UUD NRI Tahun 1945

Sofian, H. (2020). Majelis Krame Desa Wadah Selesaikan Persoalan Desa Melalui Pendekatan Hukum Adat. https://rri.co.id/mataram/daerah/741798/maje lis-krame-desa- wadah-selesaikan-persoalan- desa-melalui-pendekatan-hukum-adat, diunduh Sabtu 15 Agustus 2020

Suerti, N.N. (2019), Perkawinan Anak Dalam Perspektif Pluralisme Hukum di Indonesia, Editor: Ani Purwanti, Kunthi Tridewiyanti, Stop Perkawinan Anak Dan Penghapusan kekerasan Seksual Bagi Perempuan Dan Anak, Penerbit Thafa Media, Yogyakarta.

UU No, 16 Tahun 2019 tentang Perubahan Atas UU No.1 Tahun 1974 tentang Perkawinan 